\title{
Nilai Pendidikan Islam dalam Animasi Upin Ipin dan Signifikansinya Terhadap Sikap Toleransi Beragama Anak SD
}

\author{
Al Ihwanah ${ }^{1}$ dan Bahtiar Laha ${ }^{2}$ \\ ${ }^{12}$ Universitas Islam Negeri Sulthan Thaha Saifuddin Jambi \\ Email: ihwanah.sungudi@gmail.com
}

\begin{abstract}
Religious life in our country is being disturbed by terror issues. The pros and cons of this problem worsen the atmosphere of religious harmony. Misunderstanding of religious teachings causes intolerance. Therefore, the transformation of the value of Islamic education is an important thing that must be done immediately, especially for children as the next generation of the nation. How to cultivate this attitude of religious tolerance should take into account the characteristics of children, such as he likes fun things. Fun things kids like animated cartoons. Most of the kids love watching animated cartoons of Upin Ipin. This study analyzes the value of Islamic education in Upin and Ipin animation series, and its significance to religious tolerance of children. Based on interviews, field observations, and animated readings, this article argues that this animation teaches a character that matches the value of Islamic education. The values of Islamic education have significance in fostering religious tolerance of children.
\end{abstract}

Keywords: Islamic Education, Animation, Religious Tolerance

\section{Pendahuluan}

Isu sara yang berkedok membela agama dan golongan tertentu telah menjadi hal yang marak diberitakan. Perbedaan pendapat dan sudut pandang seseorang mengenai suatu kasus tak jarang menimbulkan perdebatan di media masa. Pro dan kontra isu teroris juga menambah keruh keadaan tersebut. Sebagian masyarakat mudah tersinggung jika ajaran agamanya dihina oleh pemeluk agama lain. Nyawa terkadang dipertaruhkan demi ego fanatik buta yang berlebihan atau terkadang pemahaman agama yang keliru mengenai jihad. ${ }^{1}$ Kekeliruan pemahaman agama itu memicu konflik antar umat seagama dan antar umat beragama. Hal itu juga menyebabkan umat terpecah ke dalam kelompok kanan dan kelompok kiri. ${ }^{2}$

\footnotetext{
${ }^{1}$ Biyanto Biyanto, "Mengurai Benang Kusut Terorisme: Memahami Penyebab, Karakter, Dan Solusi," Al-Bubuts : Jurnal Penelitian Dan Pemikiran 9 (June 2013): 151-65.

2 David A.Nadler (1970) berpendapat bahwa perilaku manusia adalah sebagai suatu fungsi dari integrasi antara person atau individu dengan lingkungannya. Berbagai karakter yang diperlihatkan oleh individu sesuai dengan jabatanya tentunya akan berbeda-beda. Dan perilakunya adalah ditentukan oleh masing-masing lingkungannya yang memang berbeda. Interaksi individu dalam masyarakat plural, memungkinkan adanya klaim kebenaran (truth claim) dan watak missioner agama menjadi pemicu benturan kehidupan beragama dan timbulnya salah pengertian antar penganut agama. Hal ini dikarenakan setiap agama menyatakan ajarannya sebagai totalitas sistem makna yang berlaku bagi seluruh kehidupan, baik
} 
Selain itu toleransi yang tumbuh dalam masyarakat kita belum berjalan normal. Oleh karena itu, pemahaman agama perlu ditanamkan pada generasi penerus secara menyeluruh demi tercapai kehidupan yang tentram, damai, dan harmonis. ${ }^{3}$ Penamaan agama Islam yang diajarkan Rasulullah SAW sebenarnya telah cukup menjadi bukti bahwa kedatangan Islam adalah untuk menghadirkan rahmat dan kedamaian bagi alam semesta. Sementara itu kedamaian tidak akan terwujud tanpa adanya suasana toleransi ditengah realitas. ${ }^{4}$ Sikap toleransi beragama perlu ditingkatkan agar komunikasi antar warga masyarakat berjalan baik. Strategi meningkatkan toleransi ini akan lebih efektif terlaksana jika menggunakan media komunikasi.

Media komunikasi yang hampir dimiliki oleh seluruh lapisan masyarakat yaitu televisi. Televisi berpengaruh positif dan negatif terhadap masyarakat. Sementara itu, sebagian besar pemirsa televisi adalah anak-anak. Adapun tayangan yang dipilih anak-anak sebagian besar film kartun atau animasi kartun. Pada saat ini, animasi yang digemari anak-anak salah satunya Upin dan Ipin. Meskipun banyak animasi dalam negeri yang bermunculan, akan tetapi Upin Ipin tetap menjadi pilihan favorit oleh sebagian anak usia SD.

Dalam tayangan Upin dan Ipin, terdapat nilai-nilai pendidikan yang disampaikan oleh adegan dari tokoh-tokoh di dalamnya yang berbeda suku dan agama. Dalam tayangannya, Upin Ipin dan kawan-kawan selalu hidup harmonis meskipun berbeda agama ini juga mengandung nilai pendidikan Islam. Oleh karena anak-anak usia SD kerap melihat animasi ini dan menirukan gaya bicaranya. ${ }^{5}$ Akan tetapi artikel ini menitikberatkan pada nilai pendidikan Islam dalam Upin Ipin.

individual maupun sosial, lihat Moh. Toriqul Chaer, "Menjaga Keutuhan Bangsa," FENOMENA 8, no. 1 (June 1, 2016): 92, https://doi.org/10.21093/fj.v8i1.542.

3 Pemahaman agama pada masyarakat pada umumnya dipahami sebagai sistem kepercayaan, tingkah laku, nilai, pengalaman dan yang terinstitusionalisasi, diorientasikan kepada masalah spiritual/ritual yang disalingtukarkan dalam sebuah komunitas dan diwariskan antar generasi dalam tradisi. Penegasan yang ingin disampaikan di sini adalah bahwa konsekuensi dari pemahaman keagamaan yang kaku, tidak bersifat scientific justru akan memunculkan stigmatisasi negatif terhadap peran penting agama dalam relasi kemanusiaan. Stigmatisasi tersebut berpandangan bahwa agama identik dengan dogmatism, rigidity, excessive self-blaming dan gender bias.

${ }^{4}$ Muhammad Yasir, "Makna Toleransi Dalam Al-Qur'an," Jurnal Ushuluddin 22, no. 2 (December 1, 2014): 170-80.

${ }^{5}$ Mika Istova and Tatat Hartati, "Pengaruh Media Film Animasi Fiksi Islami Untuk Meningkatkan Kemampuan Menyimak Dan Berbicara Siswa Sekolah Dasar," Jurnal Pendidikan Sekolah Dasar 2, no. 1 (March 1, 2016): 72-86. 
Selanjutnya, muatan nilai pendidikan Islam tersebut dicari signifikansinya terhadap sikap toleransi beragama anak usia SD.

\section{Metode Penelitian}

Penelitian ini menggunakan mixed methods dengan model sequential exploratory. Tahap pertama, dilakukan pengumpulan data dan analisis data kualitatif, selanjutnya tahap kedua dilakukan pengumpulan data dan analisis data secara kuantitatif. Metode penelitian kualitatif menggunakan content analysis yang digunakan untuk membahas secara mendalam terhadap nilai pendidikan Islam yang terkandung dalam animasi Upin dan Ipin. Hasil analisis konten dari penelitian kualitatif digunakan sebagai variabel x. Setelah analisis konten tersebut selesai, peneliti mengunakan metode kuantitatif dengan pendekatan survey untuk menentukan signifikansinya terhadap variabel y, yakni signifikansi terhadap sikap toleransi beragama anak SD.

\section{Pembahasan}

Animasi Upin dan Ipin merupakan salah satu sastra anak dengan bahasa yang digunakan sesuai dengan perkembangan intelektual dan emosional anak dengan bahasa yang mudah dipahami anak-anak. ${ }^{6}$ Berdasarkan hasil survei, anak-anak usia SD suka film animasi Upin dan Ipin. Beberapa alasan suka karena bahasa sederhana, mudah dipahami dan jalan ceritanya yang menarik perhatian anak.

Sebagai salah satu acara televisi untuk anak-anak, keberadaan Upin Ipin tidak dapat dipisahkan dengan dunia anak. Cerita yang diangkat dalam animasi Upin dan Ipin bertema kehidupan sehari-hari dan petualangan di lingkungannya. Selain itu, kebersamaan Upin Ipin dan kawan-kawan tercermin dalam permainan, peristiwa di lingkungan sekolah, kejadian di seputar rumah Upin Ipin, atau kehidupan semua tokohnya dalam pergaulan sosial di lingkungannya.

\section{a. Pengaruh dan Dampak Animasi Upin Ipin}

Sebagaimana film kartun yang lain, kartun animasi Upin dan Ipin memiliki efek kultivasi, yaitu efek yang berpengaruh sangat kuat pada diri

${ }^{6}$ Heru Kurniawan, Sastra Anak dalam Kajian Strukturalisme, Sosiologi, Semiotika, hingga Penulisan Kreatif, (Yogyakarta: Graha Ilmu, 2009), 20. 
individu yang melihatnya. Upin Ipin yang disukai anak juga akan berpengaruh sangat kuat pada diri anak tersebut. Animasi Upin dan Ipin mengisahkan tentang anak kembar seiras yang beragama Islam, hidup sederhana dan dibesarkan dalam keluarga yang berkarakter Islam. Dalam kehidupan seharihari, Upin Ipin banyak mengalami berbagai petualangan dan permaianan dengan kawan-kawan yang berlainan agama. Dalam kisah tersebut banyak ditunjukan nilai-nilai pendidikan Islam dan toleransi beragama. Sikap peduli, saling menghargai, tolong-menolong dan hidup berdampingan berbeda suku, agama serta budaya ditayangkan oleh para tokohnya. Hal ini menjadi media pendidikan nilai untuk anak-anak. Anak yang menjadikan Upin Ipin sebagai animasi idolanya akan mencontoh setiap tingkah lakunya. Dengan demikian, nilai pendidikan Islam dapat diterima dan diterapkan dalam kehidupan anak.

Animasi kartun dapat berpengaruh terhadap anak, pengaruh ini sangat besar jika ketika melihat animasi, anak berada pada posisi pasif dan tidak kritis. Sebagaimana dampak acara televisi, film animasi juga memiliki dampak, yaitu dampak informatif dan dampak peniruan. Pada dampak informatif, setiap animasi Upin Ipin yang dilihat anak akan melahirkn pengetahuan bagi anak atau pemirsa yang melihat. Dengan melihat animasi, anak secara otomatis akan menyerap informasi dan memahaminya. Selanjutnya, ada dampak peniruan, anak-anak yang melihat animasi ini akan terpengaruh untuk meniru gaya bicara, tingkah laku serta adab yang diperankan oleh Upin Ipin dan kawankawannya.

Animasi ini lucu dan membuat anak-anak tertawa. Ketika anak tertawa, pada saat yang bersamaan otak mereka sedang terangsang dan daya tangkap mereka mulai berkembang. Pada saat itulah pesan atau nilai yang terdapat dalam animasi ditransfer ke otak anak. Disadari ataupun tidak, perilaku yang ditampilkan oleh tokoh Upin Ipin dan kawan-kawan berpengaruh pada perilaku anak dalam kehidupan sehari-hari.

\section{b. Animasi sebagai Media Transformasi Nilai}

Animasi Upin Ipin menanamkan nilai pendidikan Islam pada anak-anak melalui tayangan yang bertemakan tentang ajaran Islam, seperti puasa, tarawih, ramadhan, zakat fitrah dan lain-lain. Proses belajar yang menggunakan media 
audio visual mampu meningkatkan efisiensi pengajaran 20\%-50\%. Pengalaman itu dapat menambah pengetahuan manusia 75\% diperoleh melalui indra penglihatan dan $25 \%$ didapatkan dengan indra pendengaran. ${ }^{7}$

Transformasi nilai dapat ditunjukan dari beberapa hal di antaranya tayangan Upin Ipin dapat melatih kreativitas anak. Dalam hal ini, tayangan Upin Ipin musim 11 tema ragam raya bagian satu mengajarkan anak untuk puasa dan menghargai umat agama lain yang tak berpuasa. Anak yang melihat episode tersebut mulai mengkhayal akan kebenaran puasa sebagaimana yang ia lihat. Hal ini dapat terlihat dari tingkah laku yang ditunjukan anak SDIT An Nahl yang semangat menjalankan puasa setelah nonton Upin Ipin berpuasa, dan anak juga berakting menjadi tokoh favorit sebagaimana terdapat dalam animasi Upin Ipin. Nilai pendidikan Islam yang ditayangkan dalam Upin Ipin memberikan motivasi anak untuk mengembangkan sikap percaya diri anak dalam menerapkan nilai tersebut dalam kehidupan sehari-hari.

Beberapa transformasi nilai dari animasi Upin Ipin kepada anak usia SD antara lain nilai moral, nilai dakwah dan nilai pendidikan Islam di dalamnya. Ini bertujuan untuk memahamkan anak-anak mengenai hidup berdampingan berbeda agama dengan tetap menjalankan ajaran agamanya masing-masing. Film animasi Upin dan Ipin merupakan media yang efektif dalam membentuk perilaku Islam bagi anak, ini terlihat banyak perubahan pola fikir dan pola sikap anak-anak SD IT An Nahl Kota Jambi setelah menonton animasi ini.

\section{c. Nilai Pendidikan Islam dalam Upin Ipin}

Adapun bentuk nilai-nilai pendidikan Islam yang ada dalam animasi Upin Ipin antara lain nilai pendidikan aqidah, nilai pendidikan akhlak, dan nilai pendidikan ibadah. Pertama, nilai pendidikan aqidah, merupakan landasan utama tegaknya ajaran islam. aqidah adalah suatu keyakinan atau kepercayaan yang menerapkan bahwa Allah itu Maha Esa, Maha Pencipta dan Maha Pengatur alam semesta dengan segala isinya. Pada intinya, nilai aqidah ini ialah tidak mempersekutukan Allah.

Muatan nilai ini ditayangkan Upin Ipin antara lain dalam episode "Puasa" dan episode-episode yang ditayangkan selama bulan Ramadhan. Ini karena

${ }^{7}$ A. Muhli Junaidi, Bermain dan Belajar Bersama Upin dan Ipin, (Yogyakarta: DIVA Press, 2009), 29. 
Upin Ipin dan kawan-kawan tetap menjalankan ajaran agamanya dengan baik dan tidak mencampuradukan agama meskipun setiap hari bermain bersama kawan yang berbeda agama, seperti Jajrit beragama Budha dan Mei Mei beragama Kon $\mathrm{Hu}$ Chu. Dapat dikatakan, dalam hampir setiap episode animasi ini juga mengajarkan aqidah yang kuat. Nilai aqidah dalam Upin Ipin ini ditunjukan dengan sikap mereka yang tetap tegak menjalankan aqidahnya dan bersikap toleransi dalam keyakinan dan menjalankan peribadatan. Ini sesuai dengan toleransi dalam ajaran Islam yang menolak sinkretisme.

Animasi ini juga mengandung muatan nilai aqidah untuk takut kepada Allah. Ini sangat penting dalam kehidupan orang beriman karena hal itu dapat menjadi motivasi untuk taqwa kepada-Nya. Rasa takut kepada Allah dipandang sebagai salah satu tiang penyangga iman dan merupakan landasan penting dalam pengokohan keimanan seorang. ${ }^{8}$ Nilai aqidah dalam animasi ini ialah adanya penanaman rasa cinta kepada Allah dalam adegan dialog Opah dengan Upin Ipin di dalam keluarga. Ini merupakan prinsip yang harus ditanamkan pada anak. Dalam keluarga, Upin Ipin dibiasakan untuk mencintai Allah dengan diwujudkan dalam bentuk sikap bersyukur segala nikmat yang diberikan Allah kepada setiap manusia. Ini sesuai dengan perintah Allah untuk mensyukuri nikmat Allah yang tidak terhingga.

Kedua, nilai pendidikan ibadah yaitu shalat, puasa, zakat. Ajaran tentang shalat tercermin dalam tayangan Upin Ipin episode 1 tema "Esok Puasa", ketika Upin dan Ipin sedang asyik bermain kelereng di halaman, terdengar kumandang suara adzan. Selanjutnya, dalam episode 11 "Lailatul Qodar" menyampaikan nasihat tentang shalat dan puasa, berdoa, tadarus, menyimak orang tadarus, serta nasihat kalau pergi surau jangan main melainkan beribadah dan berdoa di dalam surau. Selain shalat fardhu, dalam animasi ini juga mengajarkan shalat sunah, seperti shalat sunah tharawih yang ada pada episode ramadhan. Rutinitas sholat yang dilaksanakan Upin dan Ipin adalah pembuktian bahwa mereka selalu melaksanakan ibadah magdhah yang diperintahkan Allah. Pelajaran yang dapat di cerna oleh anak usia SD sehingga

${ }^{8}$ Abuddin Nata, Pemikiran Para Tokoh Pendidikan Islam, Kajian Filsafat Pendidikan Islam (Jakarta : Raja Grafindo Persada, 2000), 71. 
mereka yang dulunya malas untuk sholat, tetapi setelah menonton film animasi Upin dan Ipin kini mereka mulai rajin melaksanakan shalat.

Nilai pendidikan ibadah yang lain yang terdapat dalam animasi ini adalah puasa. Pelajaran tentang puasa ada dalam episode 1 yang berjudul "Esok Puasa". Selain itu, pelajaran puasa juga terdapat dalam episode 3 "Nikmat" yang menyampaikan pelajaran puasa lengkap dengan sunah-sunahnya, seperti ajaran doa berbuka puasa, sunah berbuka puasa dengan minum air putih dan makan buah kurma terlebih dahulu, baru makan nasi ini yang ditayangkan ketika Upin Ipin sedang berbuka puasa bersama Opah dan Kak Ros. Dalam episode ini juga ada pesan sembahyang tharawih. Episode 5-6, dalam nasihat Opah kepada Upin Ipin, mengajarkan bahwa puasa itu harus ikhlas biar dapat pahala, jangan berharap untuk memperoleh imbalan uang. Selanjutnya, pelajaran tentang puasa ada dalam musim 11 judul Ragam Raya bagian 1, bagian 2, dan bagian 3. Hal ini juga dapat memotivasi anak untuk melaksanakan ibadah puasa yang wajib dilaksanakan umat muslim setiap bulan Ramadhan.

Selanjutnya, nilai pendidikan ibadah zakat. Ini terdapat dalam episode 15 "Zakat Fitrah", yaitu ketika Upin Ipin sedang main di sekitar surau, mereka melihat panitia zakat di surau tersebut. Hal itu mengingatkan Opah untuk membayar zakat Fitrah. Lalu mereka bertiga, Opah, Upin, dan Ipin membayar zakat fitrah pada Tok Dalang. Animasi ini mengajarkan anak untuk belajar malaksanakan zakat fitrah setiap bulan Ramadhan. Selain zakat, pendidikan ibadah tentang shadaqah juga diajarkan oleh Kak Ros dalam episode 16 "malam syahdu", yaitu tayangan sedekah oleh Rose kepada Ihsan dan Fizi. Selain itu, ditunjukkan juga dalam episode 18 yang berjudul Berkat, yaitu ketika atok memberikan uang kepada Upin dan Ipin beserta teman-temannya.

Nilai pendidikan akhlak mencakup tiga kriteria yaitu akhlak manusia dengan Allah, akhlak manusia dengan sesama manusia, akhlak manusia dengan alam semesta. Pertama akhlak manusia dengan Allah. Ini ditunjukan melalui manifestasi iman dan taqwa seperti mentauhidkan Allah dengan menghindari syirik, berdo'a memohon pertolongan kepada-Nya, berdzikir di waktu pagi, siang atau pun malam, baik dalam keadaan berdiri, duduk atau pun berbaring 
dan bertawakkal kepada-Nya.

Kedua, akhlak manusia dengan sesama manusia. Akhlak ini mencakup akhlak manusia kepada semua manusia sebagai makhluk Allah, yaitu akhlak terhadap Rasulullah, akhlak kepada kedua orang tua, dan akhlak kepada masyarakat. Akhlak terhadap rasulullah, seperti menegakkan sunnahnya, membacakan shalawat dan menaati perintahnya serta meninggalkan larangannya. Akhlak kepada kedua ibu bapak, seperti berbuat baik kepada keduanya, mengucapkan kata yang sopan, tidak menyakiti perasaannya, tidak membentak, mendo'akan untuk keduanya, dan berziarah makamnya untuk orang tua yang sudah tiada. Akhlak kepada masyarakat, seperti bergaul dan tolong menolong, memenuhi aturan yang telah disepakati bersama dalam masyarakat, mentaati pemimpin, menegakkan ukhuwah Islamiyah dan solidaritas antar umat.

Ketiga, animasi ini juga mengajarkan akhlak manusia dengan alam semesta, seperti menjaga kelestarian alam, menjaga kebersihan dan keindahan alam. Dalam Upin Ipin, akhlak terhadap alam ada dalam episode 2-Air Kolah Air Laut bagian 1. Dalam episode tersebut, ada pelajaran tentang macammacam air dan bagaimana sebaiknya memperlakukan air, seperti nasihat Opah yaitu Upin Ipin dinasihati untuk tidak membuang sampah sembarangan di air selokan supaya selokan tidak mampet. Selanjutnya Episode 2 “Air Kolah Air Laut" bagian 2 mengajarkan untuk tidak boros dalam menggunaka air.

Akhlak adalah kehendak jiwa manusia yang menimbulkan perbuatan baik karena kebiasaan tanpa pmeikiran dan pertimbangan sehingga kepribadian yang kuat di dalam jiwa seseorang untuk selalu berbuat baik kepada kedua orang tuanya. Di antara akhlak terhadap orang tua yang ada dalam Upin Ipin ialah Upin Ipin selalu menghormati orang tua. Meskipun Upin Ipin yatim piyatu, tidak memiliki orang tua kandung, tapi mereka dididik oleh neneknya, Opah, untuk senantiasa menghormati orang tua dan orang yang lebih tua, seperti hormat kepada Tok Dalang, Ah Tong, dan lain-lain.

Animasi ini juga mengajarkan pendidikan akhlak kepada diri sendiri, seperti amanah. Amanah identik dengan sikap jujur dan dapat diandalkan 
dalam menjalankan komitmen, tugas dan kewajiban. ${ }^{9}$ Sebagaimana terdapat dalam Q.S. al-Anfal ayat 27 Allah memerintahkan Hamba-Nya untuk senantiasa beriman pada-Nya dan iman pada Rasul serta untuk menjaga amanat yang diberikan padanya. Surat al-Anfal ayat 27 ini jelaslah bahwa manusia harus berpaling dari akhlak yang tercela menuju akhlak yang mulia dan ayat ini melarang manusia untuk melakukan khianat dan menyuruh manusia untuk berpegang teguh pada amanah. Adapun sikap amanah yang diajarkan oleh Upin Ipin terdapat dalam adegan ketika ia berjanji untuk puasa sampai penuh, mereka pun menepati janji itu, dan ini cerminan dari sikap amanah. Amanah di sini juga erat sekali dengan sikap jujur. Kejujuran juga ditunjukan oleh Upin Ipin pada Episode 9 dan beberapa episode lainnya.

Pelajaran pendidikan akhlak dalam Upin Ipin, termasuk akhlak kepada keluarga dan kerabat, akhlak kepada lingkungan tetangga dan masyarakat, serta akhlak memuliakan tamu tanpa memandang agama, ras, suku, atau kelompok tertentu. Ini sesuai dengan ajaran Islam, agama yang sempurna, Islam datang sebagai rahmat seluruh alam. Ini menunjukan bahwa animasi ini mengandung nilai pendidikan Islam dan menyeru anak-anak dan pemirsa yang melihat untuk berakhlak baik terhadap siapa pun.

Selain berkhlak baik, animasi ini mengajarkan tolong menolong Episode 2 “Air Kolah Air Laut” bagian 2 menyampaikan pelajaran tolong-menolong yang termasuk persoalan-persoalan yang penting dilaksanakan oleh seluruh umat manusia secara bergantian. Hal itu menunjukkan ada nilai pendidikan Islam dan sesuai dengan Q.S Al-Maidah ayat 2, kita diperintahkan untuk tolong-menolong dalam kebaikan bukan tolong-menolong dalam kejahatan.

Pelajaran saling menasehati juga ada dalam animasi ini. Sikap menasehati adalah fitrah manusia. Jika ada manusia yang melanggar peraturan yang ada, otomatis orang lain yang mengetahui hal tersebut akan menasihati orang yang berbuat pelanggaran. Akan tetapi cara orang menasihati orang lain ini yang sebaiknya diperhatikan. Dalam animasi ini, diajarkan cara menasihati yang lain dengan baik dan dengan tatap menghargai orang yang dinasihati. Sikap

${ }_{9}^{9}$ Muhammad Yaumi, Pendidikan Karakter: Landasan, Pilar, dan Implementasi, (Jakarta: Kencana, 2006), 62. 
menghargai orang lain sebagaimana menghargai diri sendiri yaitu saling menjaga kehormatan seorang pemeluk agama satu sama lain. Adapun bentuk menghargai sesama dalam animasi Upin Ipin ditunjukan dalam saling kunjungmengunjungi ketika umat muslim merayakan hari raya, dan ketika umat agama lain juga merayakan hari raya, tapi menghargai di sini bukan berarti ikut melaksanakan ajaran agamanya, melainkan cukup menghargai saja, contohnya Upin Ipin dan kawan-kawan datang memenuhi undangan hari raya imlek yang di rayakan oleh Mei Mei.

Sikap menghargai juga ditunjukan dengan adab baik dan menebarkan Salam. Sikap dan kebiasaan Upin dan Ipin ketika memasuki rumah dan bertamu ke rumah orang lain, seperti pada terdapat dalam episode 15 dan hampir setiap episode yang menayangkan Upin Ipin berkunjung ke rumah orang lain dapat dipastikan ia mengucapkan salam. Ternyata ini juga memang dibiasakan di rumahnya, ketika hendak keluar atau masuk rumah maka mereka berucap salam.

Pelajaran toleransi dalam animasi Upin dan Ipin terdapat pada Episode 2 "Dugaan". episode 12 "kisah dan tauladan. Ini sesuai dengan ajaran Islam yang telah mengatur bagaimana cara bersosialisasi dengan orang yang berbeda agama. Prinsip dasar toleransi beragama dalam Islam khususnya adalah orang lain bebas melakukan sesuai dengan keyakinan ajaran agamanya tetapi orang Islam tetap meyakini keyakinan bahwa Islam adalah agama yang benar dengan tidak menistakan agama lain.

Berkat memiliki dasar aqidah yang kuat, ibadah yang dijalankan dengan istiqomah, akhlak yang baik maka Upin dan Ipin pun dapat menunjukkan sikap toleransi beragama dengan baik. Toleransi ini berdampak positif pada persatuan yang digambarkan dalam film animasi Upin dan Ipin, yaitu ketika mereka berkumpul dengan teman-temanya untuk bersilaturahmi kepada para tetangga yang terdapat pada episode 18 yang berjudul "Berkat" dan juga terdapat pada musim 11 tema Ragam Rayua bagian 3.

\section{d. Toleransi Beragama}

Toleransi beragama adalah toleransi yang mencakup masalah-masalah keyakinan dalam diri manusia yang berhubungan dengan akidah atau 
ketuhanan yang diyakininya. Seseorang harus diberikan kebebasan untuk meyakini dan memeluk agama menjalankan ibadah sesuai akidah yang dipilihnya masing-masing serta memberikan penghormatan atas pelaksanaan ajaran-ajaran yang dianut atau diyakininya. ${ }^{10}$ Secara garis besar, toleransi beragama memiliki dua jenis, yaitu toleransi beragama pasif dan toleransi beragama aktif. Pertama, toleransi beragama pasif, yaitu sikap menerima perbedaaan sebagai sesuatu yang bersifat faktual. Kedua, toleransi beragama aktif, yaitu sikap toleransi yang melibatkan diri dengan yang lain di tengah perbedaan dan keragaman. Toleransi aktif merupakan ajaran semua agama. Hakekat toleransi adalah hidup berdampingan secara damai dan saling menghargai di antara keragaman atau perbedaan. Muatan ini juga terdapat dalam animasi Upin dan Ipin yang telah menunjukkan toleransi aktif dalam kehidupannnya sehari-hari.

Toleransi beragama yang dilakukan dengan penuh kesadaran akan melahirkan sikap inklusif umat bergama. Sikap ini menganggap agama sendiri benar tetapi masih memberikan ruang untuk menyatakan keberadaan agama lain yang diyakini benar oleh umatnya. Sikap ini juga mampu menghilagkan sikap ekstrimis dan eksklusif umat beragama. Ekstrimis dan ekslusif agama biasanya melahirkan pemahaman fanatik buta dan radikalisme bahkan terorisme yang dapat membahayakan kehidupan umat beragama. Jika semua umat beragama memiliki sikap toleransi, maka tidak akan ada istilah teroris.

Toleransi beragama identik dengan sikap membiarkan agama lain dan tidak menyakiti orang atau umat beragama, baik yang seagama maupun berbeda agama. Sikap toleransi ditumbuhkan oleh kesadaran yang bebas dari segala macam bentuk tekanan. Adapun tujuan sikap ini adalah kehidupan yang aman, keamanan pribadi, harta benda dan unsur-unsur minoritas yang terdapat dalam masyarakat. Toleransi beragama mencakup masalah-masalah keyakinan pada diri manusia yang berhu-bungan dengan akidah atau yang berhubungan dengan ketuhanan yang diyakininya. Sikap tolerasnsi beragama diajarkan dalam kehidupan Upin Ipin yang hidup damai berdampingan dengan umat agama 87.

${ }^{10}$ J. Cassanova, Public Religions In The Modern World (Chicago: Chicago University Press, 2008), 
laian, bahkan teman-teman sekelas dan teman bermainnya juga berbeda agama.

\section{e. Bentuk Toleransi Beragama dalam Pendidikan Islam}

1slam mengajarkan menolong siapa pun, baik orang seagama maupun berbeda agama, terutama menolong orang miskin dan orang sakit. Pada hakikatnya, perbedaan telah dipelihara oleh Islam dan merupakan sunnah Allah yang tidak tergantikan dan tidak berubah, serta disatukan oleh Islam dalam akidah, syariat, peradaban, dan negara. ${ }^{11}$ Selain itu, Islam juga mengajarkan umatnya untuk dapat menjalin hubungan kerabat pada orang tua atau saudara muslim dan non muslim. Ini sebagaimana firman Allah dalam Q.S. Luqman ayat 15 yang memerintahkan kita tetap memperlakukan orang tua dengan baik sekalipun mereka berbeda keyakinan. Selain itu, kita juga diperbolehkan untuk memberi hadiah apada non muslim dengan tujuan untuk menjalin tali silaturrahim.

Pelajaran tentang toleransi beragama dari Upin Ipin bahwa mereka mengakui hak setiap orang. Ini merupakan penanaman keyakinan yang ada di dalam hati bahwa setiap orang memiliki hak untuk dihargai dan dihormati. Sikap menghormati keyakinan orang lain, yaitu suatu sikap memberikan kebebasan orang lain untuk berkeyakinan sesuai dengan pilihannya. Tidak ada sikap untuk pemaksaan agama, sebaliknya berperilaku baik terhadap sesama manusia.

Kehidupam demokratis dapat terwujud apabila dalam kehidupan yang damai dilengkapi dengan sentuhan-sentuhan naluri kemanusiaan. Sentuhan kasih sayang, sentuhan cinta, saling menghormati, saling menghargai, tolongmenolong, sikap lemah lembut, sopan santun, dan toleransi. ${ }^{12}$ Agree in disagreement atau setuju di dalam perbedaan yang merupakan sebuah penerimaan dan pemahaman terhadap perbedaan, karena perbedaan adalah sunnatullah. Pada animasi Upin Ipin merepresentasikan toleransi beragama berupa agree in disagreement terdapat dalam hampir tiap episode. Sikap ini

11 Muhammad Imarah, Islam dan Pluralitas: Perbedaan dan Kemajemukan dalam Bingkai Persatuan, (Jakarta: Gema Insani, 1999), 310.

12 Imam Amrusi Jailani, "Citra Islam Dalam Demokrasi Dan Toleransi: Potret Sikap Hidup Warisan Rasulullah Dan Sahabat,” Jurnal Theologia 23, no. 2 (August 1, 2017): 336-51. 
ditunjukan dengan tayangan karakter tokoh dalam animasi ini yang saling mengerti. Hal itu merupakan bentuk toleransi beragama yang paling krusial. Jika ada sikap ini, suka duka dapat berbagi bersama dan dirasakan bersama. Toleransi beragama dalam kehidupan sosial, warganya dari berbagai latar belakang, ras, dan agama sehingga kemajemukan dapat terjalin dengan baik apabila setiap orang dapat menerapkan sikap saling mengerti. Pelajaran toleransi beragama berupa saling mengerti ini bermanfaat dalam menumbuhkan sikap toleransi beragama anak.

\section{f. Karakteristik Anak Usia SD}

Berdasarkan tahap perkembangan menurut Piaget, anak usia sekolah dasar berada pada tahap operasional konkret. Pada tahap ini, kemampuan anak untuk berpikir secara logis semakin berkembang jika obyek yang menjadi sumber berpikirnya adalah obyek nyata atau konkret. Karakteristik anak usia sekolah dasar yaitu senang bermain, senang bergerak, senang bekerja dalam kelompok; dan senang merasakan atau melakukan sesuatu secara langsung.

Pertama, karakteristik senang bermain. Siswa sekolah dasar terutama yang masih berada di kelas rendah, pada umumnya masih suka bermain. Oleh karena itu, animasi Upin Ipin ini cocok dengan karakteristik anak SD karena adegan tokoh-tokohnya sering ditampilkan dalam suasana permaianan dan menyenangkan.

Kedua, karakteristik senang bergerak. Berbeda dengan orang dewasa yang bisa melakukan aktivitas monoton selama dalam waktu lama, anak usia sekolah dasar sangat aktif bergerak dan hanya bisa duduk dengan tenang sekitar 30 menit saja. Oleh karena itu animasi Upin Ipin yang tokohnya sering aktif bergerak ini sesuai dengan karakter anak yang juga demikian.

Ketiga, karakteristik senang bekerja dalam kelompok. Karakter Cik Guk (Guru) dalam animasi Upin Ipin tak jarang membagi siswanya menjadi beberapa kelompok kecil yang terdiri dari 3 sampai 5 siswa untuk mneyelesaikan tugas secara berkelompok. Animasi Upin dan Ipin mengajarkan bergaul dalam kelompok. Dengan demikian anak dapat belajar bersosialisasi, belajar bagaimana bekerja dalam kelompok, belajar setia kawan dan belajar mematuhi aturan-aturan dalam kelompok. 
Keempat, karakteristik senang merasakan atau melakukan sesuatu secara langsung. Berdasarkan tahap perkembangan kognitif Piaget seperti yang telah dijabarkan sebelumnya, siswa sekolah dasar berada pada tahap operasional konkret. Oleh karena itu hal-hal yang ia dengar tak jarang langsung dipraktekan anak, sehingga akan lebih baik apabila hal yang didengar itu berupa hal atau nilai yang positif. Nilai pendidikan Islam yang diajarkan Upin Ipin akan mereka terima. Mereka berusaha menghubungkan konsep-konsep nilai tersebut yang sebelumnya telah dikuasai dengan konsep-konsep yang baru dipelajari. Suatu konsep juga akan cepat dikuasai anak apabila mereka dilibatkan langsung melalui praktik dari apa yang diajarkan guru atau diajarkan oleh hal-hal di sekililingnya. Dan pada akhirnya anak akan praktik sebagaimana yang dilakukkan Upin ipin, misal ia melihat Upin Ipin puasa, anak ikut semangat praktik puasa. Jika anak melihat Upin Ipin zakat dan bershadaqoh maka anak juga semangat untuk praktik zakat dan shadaqoh.

\section{g. Penanaman Toleransi Anak}

Sikap toleransi dapat ditanamkan jika ada pemahaman agama yang utuh dan seimbang antara hubungan manusia dengan Tuhan dan hubungan manusia dengan manusia lain serta adanya keterbukaan. ${ }^{13}$ Dalam hal ini, untuk dapat menanamkan nilai pendidikan secara efektif, guru ataupun orang tua perlu memahami macam-macam metode dan strategi, strategi yang menyenangkan dan dapat membangkitkan motivasi anak. ${ }^{14}$

Animasi dalam hal ini merupakan sesuatu yang disukai anak. Kisah yang ditayangkan Upin Ipin dalam kehidupan sehari-hari mengajarkan anak untuk hidup damai berdampingan dengan agama lain. Ini sesuai dengan nilai pendidikan Islam bahwa toleransi dalam Islam adalah toleransi sebatas menghargai dan menghormati pemeluk agama lain, tidak sampai pada sinkretisme. Islam memiliki prinsip-prinsip dasar dalam toleransi ini, yakni menyatakan bahwa satu-satunya agama yang benar adalah Islam. Islam adalah agama yang sempurna, dan Islam dengan tegas menyatakn bahwa selain dari

${ }^{13}$ Casram Casram, "Membangun Sikap Toleransi Beragama Dalam Masyarakat Plural," Wawasan 1, no. 2 (2016): 187-98, https://doi.org/10.15575/jw.v1i2.588.

14 A Ihwanah, "Strategi The Power Of Two Dan Implikasinya Terhadap Efektivitas Pembelajaran Madrasah Ibtidaiyah," Tarbiyatuna 7, no. 1 (June 6, 2016): 103-18. 
Islam tidak benar, atau salah. Meskipun demikian, Islam juga mengajarkan kita untuk menghormati pemeluk agama lain.

Penanaman sikap toleransi beragama pada anak yang diajarkan Upin Ipin ini tidak memaksakan agama pada orang lain. Ini juga sesuai dengan nilai pendidikan Islam Q.S. Al Baqarah ayat 256 bahwa toleransi dalam hal beragama adalah tidak adanya paksaan untuk memeluk agama Islam. Islam membolekan umatnya untu hidup berdampingan dalam hal bermasyakat selama mereka tidak memusuhi dan tidak memerangi umat Islam.

Tiga cara yang dapat dilakukan untuk membimbing anak tentang toleransi yaitu keteladanan, mengendalikan keinginan diri sendiri, dan memperbaiki kesalahan. Tetapi yang paling penting adalah memberikan teladan. Keteladanan itu adalah hal yang paling penting, artinya bagaimana kita bisa mengajarkan kepada anak-anak kita mengenai toleransi kalau kitanya sendiri tidak memberikan contoh, tidak memberikan teladan toleransi itu seperti apa. Dalam hal ini animasi Upin dan Ipin memberikan teladan mengenai sikap toleransi beragama. Adapun beberapa kisah Upin Ipin yajg dpat dijadikan teladan anak yaitu Upin Ipin bersikap baik di dalam keluarga, saling melindungi satu sama lain.

Upin Ipin bersikap baik di dalam keluarga karena dididik oleh keluarga yang baik, yakni Opah yang bijak. Sebagai orang tua yang mengajarkan agar anak tidak menolak terhadap agama lain atau menjadi antipati, ini ditunjukan dalam adegan Opah (nenek) Upin Ipin sebagai orang tua yang baik di dalam keluarga. Hal ini karena orang tua menjadi panutan atau ikon dalam kehidupan anak sehari-hari di keluarga. Ketika seorang anak dididik dengan baik dan dapat bersikap baik di rumah, maka saat ia keluar rumah ia menjadi baik juga ketika berinteraksi dengan lingkungan sekitarnya.

Upin Ipin saling melindungi satu sama lain. Dalam keluarga, kak Rose melindungi adiknya, Upin dan Ipin. Animasi ini mengajarkan anak bahwa sebagai makhluk sosial, manusia dapat dipastikan membutuhkan peran manusia lain. Semua saling membutuhkan, maka simbiosis mutualisme lebih baik daripada simbiosis parasitisme. Untuk dapat simbiosis mutualisme, baik orang tua maupun anak-anak, hendaknya benar-benar menghayati agama yang 
diyakini dan mempratekannya dalam kehidupan sehari-hari.

Sebagaimana pepatah tak kenal maka tak sayang, animasi Upin dan Ipin ini mengajarkan anak untuk mengenal perbedaan dan keragaman ras, suku, dan agama. Apabila anak sudah mengenal perbedaan ini, harapannya anak akan dapat memiliki rasa sayang terhadap perbedaan tersebut. Sebaliknya jika anak tidak mengenal perbedaan agama, ini akan berbahaya pada kehidupannya mendatang. Ketika kita tidak mengenal, maka kita berasumsi yang lain-lain dan mudah diprovokasi. Akan tetapi jika anak mengenal perbedaan, kemungkinan besar mereka akan sulit untuk disuntikan benih-benih kebencian. Oleh karena itu, untuk dapat hidup harmonis dalam berbeda agama, salah satu caranya adalah umatnya berupaya saling mengenal satu sama lain.

Animasi Upin Ipin menanamkan sikap toleransi melalui rayakan perbedaan. Untuk mengajarkan perbedaan kepada anak-anak, Upin Ipin dan kawan-kawan menyangkan pengalaman hidupnya bahwa mereka saling mengunjungi hari raya umat agama lain. Dalam musim 11 tema Ragam Raya bagian 3, dikisahkan Mei Mei yang beragam Kong Hu Chu dan Jajrit beragama Budha berkunjung ke rumah Toh Dalang saat hari raya Iedul Fitri. Dan saat hari raya Imlek, Upin, Ipin, Mail dan Ihsan yang beragama Islam berkunjung ke rumah Mei Mei yang sedang merayakan Imlek. Kisah ini mengajarkan pada anak bahwa perbedaan itu sesungguhnya bukan sesuatu yang harus dipertentangkan, perbedaaan itu adalah suatu yang harus kita rayakan bersama tanpa harus mencampuradukan agama.

\section{Signifikansi Pendidikan Islam dalam Animasi Upin-Ipin}

Nilai pendidikan Islam baik pendidikan aqidah, pendidikan ibadah, maupun pendidikan akhlak dalam animasi Upin Ipin adalah suatu proses untuk menumbuhkembangkan fitrah anak melalui media animasi yang sarat dengan dasar-dasar ajaran Islam yang kuat. Keutamaan perangai dan tabiat serta sikap toleransi beragama dapat dimiliki dan diterapkan pada diri anak usia SD serta menjadi adat kebiasaan dalam kehidupan. Adapun nilai pendidikan Islam dalam Upin Ipin dan signifikansinya terhadap sikap toleransi beragama dapat dilihat dari sikap anak SD yang menunjukan siakp peduli, cinta, menghargai diri sendiri dan 
menghargai orang lain.

Pertama, sikap peduli yang terlihat dari siswa SD IT An Nahl yang senang melihat animasi Upin dan Ipin, ternyata mereka memiliki sikap peduli terhadap teman. Hal ini ditunjukan dengan sikap bersedia membantu teman yang terkena musibah meskipun ia berbeda daerah, bukan orang Jambi. Selain itu, ketika mereka belajar huruf hijaiyah, mereka bersedia membantu teman yang belum pandai membaca huruf hijaiyah.

Kedua, cinta yang terlihat dari anak SD IT An Nahl yang bersedia mengunjungi teman dan tetangga yang sakit walaupun berbeda agama. Hal ini menunjukan adanya rasa cinta terhadap sesama.

Ketiga, menghargai perbedaan dan individu. Seperti Upin dan Ipin yang berteman dengan siapa saja, anak SD IT juga berteman dengan siapa saja. Mereka bersahabat dengan teman dari berbagai daerah, memberikan salam kepada teman dari daerah lain, menerima usul dari teman lain yang berbeda agama.

Keempat, adanya kesadaran anak. Ini terlihat dari anak senang jika orang lain memberikan saran kepada saya dan ia menyadari kalau yang ia lakukan keliru. Selain itu adanya kesadaran anak untuk bersatu dengan sekolah memajukan sekolah, kesadaran anak dalam bermusyawarah dengan semua teman apapun perbedaannya.

Kesadaran bermusyawarah untuk menyelesaikan pertentangan dengan teman di sekolah, anak mendukung jika teman yang berbeda agama menjadi pemimpin. Selanjutnya kesadaran dan kesediaan menerima saran dari seluruh teman maupun guru, anak menghargai teman yang mengutarakan pendapatnya pada saat diskusi, anak menghargai perbedaan pendapat dengan teman lain. Kebersamaan di sekolah menjadi bagian penting dalam kehidupan,

Berbeda agama dengan teman lain dapat menimbulkan masalah. Perbedaan pendapat tidak menimbulkan solusi saat diskusi, perbedaan asal daerah tidak menyebabkan masalah dalam memilih teman, anak senang jika muncul perbedaan cara berbicara dengan teman, anak bermain dengan teman tanpa membedakan derajat, anak ingin belajar satu kelompok dengan semua teman tanpa membedakan rupa wajah ganteng, cantik, atau tidak keduanya.

Kelima, menghargai perbedaan orang lain. anak berteman tanpa 
membedakan warna kulit teman lain, anak bersedia satu bangku dengan teman kaya atau miskin, anak bersedia memberikan salam kepada teman yang tidak disukai, anak menghargai tutur bahasa teman yang berasal dari luar Jambi, anak menolong teman yang sedang dalam musibah, anak tidak menganggap bahwa dirinya yang paling benar dibanding teman lain, anak senang saat ada diskusi dengan teman lain.

\section{Catatan Akhir}

Animasi Upin dan Ipin mengandung nilai pendidikan Islam, yaitu nilai pendidikan aqidah, akhlak dan ibadah. Pertama, kandungan nilai pendidikan aqidah meliputi keyakinan atau iman yang diajarkn oleh Upin Ipin mengenai iman kepada Allah dan iman kepada Rasul Allah. Kedua, nilai pendidikan akhlak, meliputi akhlak terhadap Allah seperti khusyu, ikhlas dan bersyukur atas nikmat Allah, akhlak pribadi yang meliputi patuh, sabar, akhlak terhadap orang lain seperti dermawan, toleransi, peduli, dan pemaaf.

Nilai pendidikan Islam dalam Upin Ipin memiliki pengaruh yang cukup signifikan terhadap sikap toleransi beragama anak usia SD. Sifat naluri anak meniru perilaku atau perbuatan dilihat dan didengar dari animasi tersebut. Oleh karena itu, para orang tua diharapkan dapat mendampingi anak dalam melihat animasi. Ini bertujuan agar anak memiliki pamahaman yang benar dan utuh, serta tidak salah paham terhadap nilai pendidikan yang disampaikan melalui animasi tersebut.

Nilai pendidikan Islam yang ada dalam animasi ini dapat ditransfer ke otak anak dengan baik. Anak yang memiliki pemahaman nilai ajaran Islam dengan baik, maka ia akan dapat memiliki sikap toleransi beragama dengan baik. Selanjutnya, anak dapat tumbuh menjadi generasi yang pandai menghargai perbedaan, tidak menistakan agama lain dan dapat hidup damai dengan umat seagama dan dengan umat berbeda agama.

\section{Daftar Rujukan}

Biyanto, Biyanto. "Mengurai Benang Kusut Terorisme: Memahami Penyebab, Karakter, Dan Solusi." Al-Bubuts: Jurnal Penelitian Dan Pemikiran 9 (June 2013): 151-65. Casram, Casram. "Membangun Sikap Toleransi Beragama Dalam Masyarakat Plural." Wawasan 1, no. 2 (2016): 187-98. https://doi.org/10.15575/jw.v1i2.588. 
Chaer, Moh. Toriqul. "Menjaga Keutuhan Bangsa." FENOMENA 8, no. 1 (June 1, 2016). https://doi.org/10.21093/fj.v8i1.542.

Ihwanah, A. "Strategi The Power Of Two Dan Implikasinya Terhadap Efektivitas Pembelajaran Madrasah Ibtidaiyah.” Tarbiyatuna 7, no. 1 (June 6, 2016): 103-18.

Istova, Mika, and Tatat Hartati. "Pengaruh Media Film Animasi Fiksi Islami Untuk Meningkatkan Kemampuan Menyimak Dan Berbicara Siswa Sekolah Dasar." Jurnal Pendidikan Sekolah Dasar 2, no. 1 (March 1, 2016): 72-86.

Jailani, Imam Amrusi. "Citra Islam Dalam Demokrasi Dan Toleransi: Potret Sikap Hidup Warisan Rasulullah Dan Sahabat.” Jurnal Theologia 23, no. 2 (August 1, 2017): 336-51.

Yasir, Muhammad. "Makna Toleransi Dalam Al-Qur'an.” Jurnal Ushuluddin 22, no. 2 (December 1, 2014): 170-80. 